\title{
Wielding Bibliography
}

\section{Nick Mount*}

Bibliography matters. Lists matter. Matter matters.

Saying that here, to you, needs no courage. Telling bibliographers that bibliography matters is like telling chiropractors that chiropractic matters: a safe bet in an easy room, us against the unenlightened, reassurance over coffee and cupcakes. To tell a booklover that books reward the bibliographer's backward love as much as the reader's forward lust is not news for the booklover.

Not being news, it also needs no evidence, not here. Every literature, in every period, has its stories of how close study of the written or printed record has changed the record, revising dates, authors, and interpretations. Bibliography is the bedrock of these stories. As an old bookseller told a young John Metcalf, "Catalogues are where all the knowledge sifts down to."

Periodically, bibliographers nonetheless gather to remind ourselves we matter, to ask for new evidence for an argument that, for us, needs no argument. The Fourth National Conference on the State of Canadian Bibliography in Montreal in June of 2007 was one such gathering. Specifically, the organizers asked the panel I was on - "The Place of Bibliography in the Academy Today" - to talk about how bibliography mattered to our work, to us: a new professor, a new $\mathrm{PhD}$, and a current graduate student.

So we did. Linda Quirk talked about the lack of bibliographical training offered to graduate students at Queen's University, mentioning an assumption that bibliographical skills can be acquired en route and the existence of a general disdain for "mere bibliographers." Eli MacLaren talked about how analytical bibliography helped his dissertation explain why post-Confederation Canadian publishers

\footnotetext{
* Nick Mount teaches Canadian literature at the University of Toronto. He is the author of When Canadian Literature Moved to New York (Toronto: University of Toronto Press, 2005), winner of the 2005 Gabrielle Roy Prize.

I John Metcalf, An Aesthetic Underground: A Literary Memoir (Toronto: Thomas Allen, 2003), 21.
} 
became distributors instead of publishers. ${ }^{2}$ I talked about how lists of books made my first book possible, lists that showed most Canadian writers publishing elsewhere in the I880s and I890s and that led to the discovery that most of them also moved elsewhere. ${ }^{3}$

There's nothing inherently wrong with such reminders. The stories they tell can be interesting in and of themselves. And it's good for the soul and mind of any profession to meet itself, to refresh memories of faces and ideas and learn new ones. The problem with bibliography today isn't what it's saying. The problem is who it's saying it to. The problem is not bibliography's shrinking "place" in the academy. It is its shrinking audience. The problem is us.

When I did the bibliographical work for the dissertation that became my book, I didn't know my verso from my recto. Bibliography was still useful to me, but I've no doubt that it would have been more useful, never mind easier, if I had known what I was doing instead of making it up as I went along. I took a required course as part of my MA that ostensibly included bibliographical methods. But at the time the Internet was all bright and shiny, so we spent most of our time learning how to join electronic discussion groups. And all I learned from that was to avoid electronic discussion groups.

As Linda explained, my ignorance of bibliography has become typical. Most Canadian universities no longer teach bibliography to graduate students. If they do, it's as a workshop or two in a professional development course, squeezed in among units on preparing a teaching dossier, dressing for success, and how to give Sally a "B" without losing your job. I'm happy to say that's not the case at my current home, the Department of English at the University of Toronto, which still has enough old ideas (and, admittedly, old money) to require all $\mathrm{MA}$ and $\mathrm{PhD}$ students to take a half-year course devoted exclusively to bibliography.

But I gather from Linda that the University of Toronto is now the exception, not the rule. And that's odd. It's odd because for at least a decade, the book has been the talk of English literary studies. At the 2005 convention of the Modern Language Association (MLA), the humanities editor for Oxford University Press confirmed the

2 Eli MacLaren, "The Economics of Literary Production: Copyright and Publishing in English Canada, $1867-1920$ " (PhD diss., University of Toronto, 2007).

3 Nick Mount, When Canadian Literature Moved to New York (Toronto: University of Toronto Press, 2005). 
dominance of "print culture" studies in an academic market that continues its fascination with book history, singled out back in 1993 by the Chronicle of Higher Education as "a particularly hot topic in the humanities." 4

So, precisely at the time when students of literature could use some real training in the materials and history of the physical text in its many formats - in how and why matter matters - we're not getting it or giving it. A few years ago, the editor of Studies in Bibliography, our plenary speaker David Vander Meulen, pointed out that book history has become a discipline that studies not books but ideas about books, ideas based on very little bibliographical knowledge and evidence. ${ }^{5}$ Here in Canada, my colleague Alexandra Gillespie has just finished an absurdly well-read survey of book-history scholarship for the journal New Medieval Literatures that reaches the same conclusion from a medievalist's perspective: that book history deals more with the cultural contexts for books than with books themselves, let alone manuscripts - that, weirdly, book history sucks at books. ${ }^{6}$

Book history and bibliography aren't completely divorced, but they might as well be: they sleep in separate beds. On book history's side, the Society for the History of Authorship, Reading and Publishing (SHARP), formed in 1991. On bibliography's side, the venerable Bibliographical Societies of Britain (1892), America (1904), and Canada (1946). If they went to court today, SHARP would win custody: its membership is now larger than any bibliographical society. ${ }^{7}$ Book history has been for some time now a much bigger deal than bibliography: younger, hotter, sexier. Not surprisingly, ideas about books turned out to be more interesting than lists of books, even ideas based on badly done lists, like mine. Add the cold truth that book history gets published by major presses and journals and bibliography does not, that book history gets jobs and bibliography does not, and it's also not surprising that bibliographical societies

4 Jennifer Howard, "Hot Type: At the MLA, Publishers Discuss What's New," Chronicle of Higher Education, I3 January 2006, AI7; Karen J. Winkler, "In Electronic Age, Scholars Are Drawn to Study of Print," Chronicle of Higher Education, I4 July 1993, A7.

5 David L. Vander Meulen, "How to Read Book History," Studies in Bibliography 56 (2003-4): 17I-93.

6 Alexandra Gillespie, "Analytical Survey: The History of The Book," New Medieval Literatures 9 (2007): 245-86.

7 Ibid. 
tend to be home to the, umm, happily tenured, while the young and hungry flock to SHARP.

Bibliographers have a choice. We can continue to talk to ourselves, to enjoy the stories we tell and lament the lack of expertise and understanding outside the healing circle. We can maintain our dwindling societies, claiming the methodological high ground while the book-history tide rises around us. Perhaps that tide will turn on its own and suddenly realize by itself that bibliography matters.

Or, we could disband our societies, starting with this one, and rejoin the field. We could give talks at, publish with, and meet the faces and ideas in other and general societies - not in the ghetto of specialized panels, but out in the general fray, bibliographers mixing with cultural historians, theorists and post-theorists, the old new critics and the new old aesthetes. If we did that, we might demonstrate the potential to all breeds of literary studies of knowing how to do bibliography, if not expertly then at least better. And we might learn something ourselves about what to do with all these lists and descriptions, what sorts of ideas they could be hiding, what Derrida or Eagleton might have to do with signatures and fonts.

It's fine for Jane Austen to have her own society, people who care more about Jane than anything else. It's a little weird, but no weirder than many another pursuit of happiness. But bibliography isn't an end: it's a means to an end, a way to do literary history, literary criticism, and especially book history better. Jane Austen is not a tool; bibliography is. To my mind, it's a foundational tool, one everyone who studies literature should know how to use. Making lists is the first step in literary studies: without lists, you get literary history wrong, and you leave your criticism open to error. Overlooking American publications by Canadian writers, for instance, got our literary history and our literature wrong by making it look much more Canadian than it really was.

In better hands than mine, bibliography offers much more than lists. The bibliographical expertise of the contributors to the recently completed History of the Book in Canada (many of them members of the Bibliographical Society of Canada) has, for instance, enriched, challenged, and changed the literary history of Canada yet again. ${ }^{8}$ Those contributors shouldn't be telling bibliographers that

8 Patricia Lockhart Fleming and Yvan Lamonde, eds., History of the Book in Canada, 3 vols. (Toronto: University of Toronto Press, 2004-7). 
bibliography helped do all that; they should be telling the Association of Canadian College and University Teachers of English (ACCUTE), the MLA, and especially SHARP. The best way to prove bibliography matters isn't to tell people who already believe that bibliography matters. The best way is to tell, and even better, show people who don't think it matters that it can matter. And I suggest, respectfully, that the best way to do that might be to stop talking to each other, and start talking to the field.

\section{SOMMAIRE}

Si la bibliographie est en déclin comme discipline au Canada, il faut en jeter le blâme aux bibliographes eux-mêmes qui ne sont pas parvenus à démontrer la pertinence de leur travail dans le vaste milieu universitaire. L'intérêt que suscite l'histoire du livre est partout en progression et les méthodes bibliographiques mises à contribution dans le domaine de la recherche ne font aucun doute. Les bibliographes devraient par conséquent faire ressortir l'utilité de leur discipline non pas à l'intérieur de leurs propres associations mais au contraire par le biais d'importants congrès comme ceux qu'organisent par exemple la Society for the History of Authorship, Reading and Publishing (SHARP), l'Association of Canadian College and University Teachers of English (ACCUTE) et la Modern Language Association (MLA). 
